\title{
Procedural Rights Supporting Expeditious Trials for Juveniles
}

\section{Effective Remedies and Legal Representation}

\author{
Aekje Teeuwen* \\ $\mathrm{PhD}$ researcher, Leiden University Law School, Department of Child Law, \\ Leiden, The Netherlands \\ aekje@yahoo.com
}

\begin{abstract}
Delays pending trials can negatively impact juveniles. Encouragingly, the right of juvenile defendants to be tried within a reasonable time has been enshrined in international and regional human rights instruments. To support and strengthen the realisation of this specific right, several additional procedural entitlements, to which existing scholarship has paid limited attention, are of importance. This article focuses on how the rights to an effective remedy and legal representation can support the fulfilment of expeditious trials for juveniles. Furthermore, it analyses to what extent these two identified rights have been incorporated into significant international human rights standards and, specifically, in the Cambodian, Philippine and Vietnamese legislative frameworks. It identifies lessons Cambodia can draw from the latter two countries.
\end{abstract}

\section{Keywords}

juvenile justice - reasonable time - delays in criminal trial proceedings - effective remedies - legal representation - Cambodia, The Philippines, and Vietnam

* External PhD researcher at Leiden University Law School, Department of Child Law, Leiden, The Netherlands. The author would like to thank Prof Dr Ton Liefaard and Dr Stephanie Rap for their great guidance and valuable comments on earlier drafts of this article. 
A fundamental human right of juvenile defendants is the right to be tried within a reasonable time, ${ }^{1}$ which has been explicitly and implicitly enshrined within the majority of the international and regional human rights instruments. ${ }^{2}$ Previous research has demonstrated that a violation of this right has a particularly detrimental impact on juveniles (specifically when deprived of their liberty), negatively affecting their development, and overall wellbeing, diminishing their educational opportunities and future employment prospects, as well as offering a reduced deterrent effect and heightened chances of recidivism. ${ }^{3}$

1 In this article, the term 'the right to be tried within a reasonable time' and 'the right to an expeditious trial' are used interchangeably, referring to the same right as applied in the relevant international and regional instruments. The International Covenant on Civil and Political Rights (adopted 16 December 1966, entered into force 23 March 1976) 999 UNTS 171 (ICCPR), art 9(3) and the Convention for the Protection of Human Rights and Fundamental Freedoms (European Convention on Human Rights, as amended) (ECHR), arts 5(3) and (6) (1), both refer to the right to be tried within a reasonable time. The United Nations Standard Minimum Rules for the Administration of Juvenile Justice, GA Res. 40/33, 29 November 1985 (Beijing Rules), $\mathrm{r} 2 \mathrm{O}(1)$ and the United Nations Rules for the Protection of Juveniles Deprived of their Liberty, GA Res. 45/113, 14 December 199 o (Havana Rules), r 17, acknowledge the critical significance of the 'expeditiousness' of processing in legal proceedings for children.

2 ICCPR, arts 9(3), 1O(2)(b) and 14(3)(c); Convention on the Rights of the Child (November 1989) 1577 UNTS 3 (CRC), art 4O(2)(b)(iii); ECHR arts 5(3) and 6(1); American Convention on Human Rights (adopted 22 November 1969, entered into force 18 July 1978) (ACHR), art 8(1); African Charter on Human and Peoples' Rights (adopted 27 June 1981, entered into force 21 October 1986) (1982) 21 ILM 58 (African Charter), art 7(1).

3 Carol Ann Burgess, Recidivism of Juvenile Burglars: A Perceptual View of Specific Deterrence. Doctoral Dissertation (University of Arizona 1982); Jeffrey A Butts and Joseph B Sanborn Jr., 'Is Juvenile Justice just too Slow?' (1999) 83(1) Judicature 16; Robert E Shepherd Jr, 'Speedy Trials for Juveniles' (2000) 14(4) Criminal Justice 53; Thomas Grisso et al, 'Juveniles' Competence to Stand Trial: A Comparison of Adolescents' and Adults' Capacities as Trial Defendants' (2003) 27(4) Law and Human Behavior 333; Yair Listokin, 'Crime and (with a Lag) punishment: The implications of discounting for equitable sentencing' (2007) 44 American Criminal Law Review 115; Jeffrey A Butts, Gretchen Ruth Cusick and Benjamin Adams, Delays in Youth Justice (University of Chicago 20o9); Sinead Freeman and Mairead Seymour, “Just Waiting": The Nature and Effect of Uncertainty on Young People in Remand Custody in Ireland' (2010) 10(2) Youth Justice 126; Richard A Mendel, No Place for Kids: The Case for Reducing Juvenile Incarceration (The Annie E. Casey Foundation 2011); Bart Lubow, Timely Justice: Improving JDAI Results Through Case Processing Reforms (The Annie E. Casey Foundation 2017); Juvenile Justice Advocates International and the University of Minnesota Law School Human Rights Center, Children in Pretrial Detention: Promoting Stronger International Time Limits (Juvenile Justice Advocates International and the University of Minnesota Law School Human Rights Center 2018); Aekje Teeuwen, 'Juvenile Defendants' Right to be Tried within a Reasonable Time in Cambodia: An International Human Rights Analysis' (2019) 19(1) Youth Justice 42; UN 
Several procedural rights, if exercised properly, may positively impact the expedition of legal proceedings for juveniles and consequently contribute to the reduction of delay. In this context, two of those rights have been selected due to their high level of relevance. Firstly, the right to an effective remedy, as the fulfilment of this right may result in the prevention of delay and compensation in case of a delay. Secondly, the right to legal representation, ${ }^{4}$ as the role of the lawyer is essential throughout the process in relation to the realisation of the defendants' remedial rights.

Research on the right to an effective remedy in the case of a breach of an expeditious trial, including the different forms and practices, as well as on the right to legal representation for juveniles, has been extensively conducted by several authors in previous studies. ${ }^{5}$ Nevertheless, specific in-depth research on the remedies pertinent to delays for juvenile defendants, as well as on the two identified procedural rights and their specific relevance to the expedition of trial proceedings, appears to be sparse and limited globally, and certainly inadequate to non-existent within the context of the Southeast Asia region, including Cambodia, the Philippines, and Vietnam. ${ }^{6}$

Committee on the Rights of the Child, children's rights in the child justice system (2019). General Comment No 24, CRC/C/GC/24, paras 54, 55, 77, 86 and 9o.

4 'The right to legal representation' in this article refers to the right to legal and other appropriate assistance.

5 Catrinel Brumar, "The Virtues of an Acceleratory Remedy in the Fight against the Excessive Length of Judicial Proceedings' (2011) Challenges of the Knowledge Society 823; Tatjana Zoroska Kamilovska, 'Legal Remedies for the Protection of the Right to a Trial within a Reasonable Time - Macedonian Perspective' (2012) 3(1) Iustinianus Primus Law Review; Martin Kuijer, 'The Right to a Fair Trial and the Council of Europe's Efforts to Ensure Effective Remedies on a Domestic Level for Excessively Lengthy Proceedings' (2013) 13(4) Human Rights Law Review 777; Ton Liefaard and Yannick van den Brink, 'Juveniles' Right to Counsel during Police Interrogations: An Interdisciplinary Analysis of a Youth-Specific Approach, with a Particular Focus on the Netherlands' (2014) 7(4) Erasmus Law Review 206; Anne Bleeker, Overschrijding van de redelijke termijn in jeugdstrafzaken in Nederland, Engeland en Wales. Masterscriptie Jeugdrecht (Universiteit Leiden 2016); Emily Buss, 'What Stands in the Way of Children's Exercise of their Criminal Procedural Rights in the United States? Our Evolving and Incomplete Interdisciplinary Understanding' in Martin D. Ruck, Michele Peterson-Badali and Michael Freeman (eds), Handbook of Children's Rights: Global and Multidisciplinary Perspectives (Routledge 2016); Stephanie Rap and Daniella Zlotnik, 'The Right to Legal and Other Appropriate Assistance for Child Suspects and Accused' (2018) 26(2) European Journal of Crime, Criminal Law and Criminal Justice 110; Ton Liefaard, 'Access to Justice for Children: Towards a Specific Research and Implementation Agenda' (2019) 27(2) International Journal of Children's Rights 195 .

6 This article forms part of the authors' PhD research, of which the Southeast region of Cambodia is the focus, as the author has lived and worked there in the field of juvenile justice for many years. 
Consequently, the central research question of this article is how the rights to an effective remedy and legal representation can support the realisation of expeditious trials for juveniles. To what extent have these two identified rights been incorporated into relevant international human rights standards, and the Cambodian, Philippine and Vietnamese legislative frameworks?

Several sub-questions have been examined:

1. What are the impacts of delays on juvenile defendants from a psychological and educational perspective? ${ }^{7}$

2. To what extent can the identified supporting rights contribute towards the prevention and/or reduction of delay?

3. To what extent have Cambodia, the Philippines and Vietnam incorporated the identified supporting rights into their national legislative frameworks, and could some of the findings serve as positive examples for Cambodia?

The aim of this article is to identify how procedural rights can support the right to an expeditious trial for juvenile defendants, and whether lessons from relevant regional jurisdictions in relation to these rights can be drawn for Cambodia. ${ }^{8}$ This article will contribute to existing literature focusing on the conceptualisation and reflection of the 'reasonable time' requirement and delay in criminal proceedings, with a focus on juvenile defendants. In particular, it discusses the potential negative impact of delay on juveniles from a psychological and educational perspective, as well as the positive effect 'supporting rights' may have on the 'reasonable time' requirement. To ensure the response and conclusion to the proposed research question are accurately captured, a number of methodological approaches have been utilised, involving a literature review, as well as an assessment of the relevant international and regional human rights framework, and the Cambodian, Philippine and Vietnamese legislative structures.

7 The author, as part of her $\mathrm{PhD}$ research, has previously published an article in Youth Justice, entitled: 'Juvenile Defendants' Right to be Tried within a Reasonable Time in Cambodia: An International Human Rights Analysis', which included several impacts delay may have on juvenile defendants. In this article the impacts of delays on juvenile defendants will be further addressed, however from a psychological and educational perspective, which had not been elaborated upon to the same extent in the previous article.

8 Vietnam has been selected as a country of focus as it is an adjacent neighbour of Cambodia and has had an extensive post war influence throughout Cambodia's reconstruction period. The Philippines has been selected because of its extensive legislative framework relevant to this article's topic. In both these countries the majority of the legislative framework has been translated into English, which is convenient for the author to access sources. 
First, it is necessary to reflect on the concept of 'reasonable time' within the context of criminal justice proceedings, as well as from a psychological and educational perspective to ascertain the diverse effects delay may have on juveniles, compared to adults. The outcome from this analysis will be a review of the child specificity within human rights instruments, as well as the additional safeguards required to be embedded into those instruments for the consideration and benefit of juveniles. Further, the key procedural rights supporting expeditious trials for juveniles will be presented and examined, consisting of the right to an effective remedy and the right to legal representation. Lastly, an assessment will be conducted of the extent to which Cambodia, the Philippines and Vietnam have incorporated the abovementioned two procedural rights into their national legislative frameworks. The article will end with a conclusion and recommendations. ${ }^{9}$

This section underlines the importance of ensuring a balance between 'reasonable time' and the 'administration of justice', including in relation to fair trial rights. Furthermore, to demonstrate the importance of being tried within a reasonable time, this section outlines the impact of delay on juvenile defendants from a psychological and educational perspective.

\subsection{Reflection on Reasonable Time Versus Fair Trial}

It is of vital importance that trial proceedings are executed within a reasonable time. ${ }^{10}$ Expeditiousness though cannot be executed at the expense of the sound 'administration of justice.'1 In this context, the concept of 'reasonableness'

$9 \quad$ It should be noted that, given the distinct differences between child offenders and child victims, for the purpose of this article, the focus will be predominately on the perspective of the juvenile offender. Therefore, the article will not elaborate further upon the procedural rights and interests of other relevant parties concerned within the juvenile justice process, such as the victim.

10 Sam K Amoo, "The jurisprudence of the rights to trial within a reasonable time in Namibia and Zambia' (2010) 2(2) Namibia Law Journal 3; Butts, Cusick and Adams (n 3); Butts and Sanborn Jr (n 3); Zvikomborero Chadambuka, 'Serious Offences and the Right to Trial within a Reasonable Time' (2012) 9(1) Essex Human Rights Review 1; Sandra Kaija, 'Completion of Criminal Proceeding within a Reasonable Time in Latvia' (2013) 20(2) Jurisprudencija 725; Kuijer (n 5); Marc Henzelin and Héloïse Rordorf, 'When Does the Length of Criminal Proceedings Become Unreasonable According to the European Court of Human Rights?' (2014) 5(1) New Journal of European Criminal Law 78; Lubow (n 3). Gast and Popp v Germany App no 29357/95 (ECtHR, 25 February 200o), para 75. 
should mirror the crucial 'balance' between on the one hand prompt and on the other hand 'fair proceedings.'12 Accordingly, important 'defence rights', 13 such as 'access to a court, the equality of arms' and the right to have sufficient time to prepare for a defence, should not be weakened by the desire for expeditious procedures. ${ }^{14}$

The importance of achieving the right balance between rapid and fair proceedings for juveniles is also highlighted by the UN Committee on the Rights of the Child (CRC Committee). This specific body recommends States parties to establish and implement time limits between the different phases of the criminal process for cases involving juvenile defendants, and to ensure these time limits are substantially briefer than those for adults, "but should still allow legal safeguards to be fully respected. ${ }^{15}$

A fundamental component of a fair trial, which should not be disregarded at the cost of 'speediness', is the 'equality of arms' principle, which has been explicitly or implicitly enshrined in the majority of prominent international and regional human rights instruments ${ }^{16}$ and case law. The UN Human Rights Committee (HRC) states that the principle of 'equality of arms' demands that 'each party must be afforded a reasonable opportunity to present his case under conditions that do not place him at a substantial disadvantage vis-à-vis his opponent'17 and be treated 'without any discrimination. ${ }^{18}$ The HRC highlights that this principle is not respected where, for instance, the accused is 'unable to properly instruct his legal representative' due to the absence of a lawyer. ${ }^{19}$

Thus, in order to guarantee a fair trial, 'an effective prosecution as well as effective defence' are wholly necessary. ${ }^{20}$ Consequently, the 'equality of arms'

12 Council of Europe, Report on the effectiveness of national remedies in respect of excessive length of proceedings (Council of Europe 2007), para 17. See also Acquaviva v France App no 19248/91 (ECtHR, 21 November 1995), para 66; Niderhöst-Huber v Switzerland App no 1899o/91 (ECtHR, 18 February 1997), para 30; European Union Agency for Fundamental Rights and the Council of Europe, Handbook on European law relating to access to justice (Publications Office of the European Union 2016) 140.

13 European Union Agency for Fundamental Rights and the Council of Europe (n 12), para 7.2.

14 Council of Europe (n 12), para 22. See also European Union Agency for Fundamental Rights and the Council of Europe ( $\mathrm{n} 12$ ), para 7.2.

15 UN Committee on the Rights of the Child (n 3), para 55.

16 ICCPR, art 14; CRC, art 40; ECHR, art 6.

17 De Haes and Gijsels v Belgium App no 19983/92 (ECtHR, 24 February 1997), para 53.

18 UN Human Rights Committee, Article 14: Right to Equality before Courts and Tribunals and to a Fair Trial (2007). General Comment No 32, CCPR/C/GC/32, para 8.

19 Wolfv Panama no 289/1988 (HRC, 8 April 1992), para 6.6.

20 Shajeda Akther and Rohaida Nordin, 'Equality of Arms: A Fundamental Principle of Fair Trial Guarantee Developed by International and Regional Human Rights Instruments' (2014) Legal Network Series 1 LNS(A) lii. 18. 
principle can be deemed particularly important for the 'weaker party', which is often the (juvenile) defendant. ${ }^{21}$ The CRC Committee underlines, in its General Comment No 24 on children's rights in juvenile justice, the relevance of the 'equality of arms' principle, that '[c]hildren have the right to examine witnesses who testify against them and to involve witnesses to support their defence, and child justice processes should favour the child's participation, under conditions of equality, with legal assistance. ${ }^{22}$

Furthermore, 'the quality of the legal reasoning and the extent to which judgments are motivated and made transparent to the parties and to the public', are also critically essential and must be given great attention. ${ }^{23}$ As the European Commission for the Efficiency of Justice (CEPEJ) addressed, 'meticulously drafting a decision, weighing up the reasons for it, and making it clear and comprehensible are all operations that take time', which could hasten a decision to lighten the requirements for providing reasons for a decision'. Nevertheless, 'a decision with clearly stated reasons allows the parties to accept it more easily'. Well-founded decisions of first instance may also likely result in a diminishment of appeals ${ }^{24}$ (see also section 3.1.5. below on 'appeal' in this article). ${ }^{25}$ In addition, the requirement for expeditiousness in proceedings must not compromise the need to protect the independent status of the judiciary in arranging 'its own procedures without undue internal and external' influences. $^{26}$

21 Masha Fedorova, The Principle of Equality of Arms in International Criminal Proceedings (Intersentia 2012) 37 and 440. See also Salduz v Turkey App no 36391/o2 (ECtHR, 27 November 2008), para 53; Stefania Negri, 'The Principle of Equality of Arms and the Evolving Law of International Criminal Procedure' (2005) 5(4) International Criminal Law Review 513, 513 and 570 .

UN Committee on the Rights of the Child (n 3), para 61.

23 Council of Europe (n 12), para 23. See also Council of Europe, A new objective for judicial systems: the processing of each case within an optimum and foreseeable timeframe (European Commission for the Efficiency of Justice (CEPEJ) 2005) CEPEJ 200419 REV 2; Cambodian Center for Human Rights (CCHR), The Right to a Reasoned Judgment (CCHR 2018).

24 Council of Europe (n 23), second pt, para 2. See also Council of Europe (n 12), para 23.

25 The CEPEJ states that ' $t$ ] he objective of reducing the length of proceedings must result in each case being completed in an optimum time which satisfies at the same time the society, the parties, the victims and the accused persons, etc.' Each case must be processed within an 'optimum and foreseeabletime frame' (Council of Europe (n 23). See also Council of Europe (n 12), para 25).

26 Council of Europe (n 12), para 24. See also Council of Europe (n 23). 


\subsection{Reflection on 'Reasonable Time' from a Psychological and Educational Perspective}

Youth develop significant cognitive and emotional skills during adolescence. The manner in which they comprehend situations and their ability to make mature judgments may differ from adults, as a result of their 'psychosocial immaturity'. ${ }^{27}$ Their psychosocial immaturity impacts their overall ability to defend themselves or 'the competence to stand trial', which, as previous literature shows, depends on two factors. First, the competence 'to assist counsel', referring to the defendant's comprehension of the criminal procedures and an ability to provide the legal counsel with all the necessary information regarding the case. Secondly, the competence to 'make decisions', referring to the defendant's capability to decide on various legal options in the process, such as filing an appeal. ${ }^{28}$

Juvenile defendants, it has been argued, differ considerably in their abilities to contribute to their own defence and subsequently to the criminal process as a whole, which is also referred to as 'effective participation.29 In addition to the developmental barriers a juvenile may typically face, the ability of a juvenile to stand trial and to effectively participate in the process may also be negatively impacted by delays in proceedings. Research has indicated differentiated time perspectives between adolescents, who are more 'present-oriented', compared to adults, who are more 'future-oriented' ${ }^{30}$ Within the context of time and

27 Grisso et al (n 3); Laurence Steinberg and Elizabeth Scott, 'Less guilty by reason of adolescence: developmental immaturity, diminished responsibility and the juvenile death penalty' (2003) 58(12) American Psychologist 1009, 1012; Stephanie Rap, The participation of juvenile defendants in the youth court: A comparative study of juvenile justice procedures in Europe (2013) (PhD thesis Universiteit Utrecht) Pallas publications; International Juvenile Justice Observatory, Can anyone hear me? Participation of children in juvenile justice: A manual on how to make European juvenile justice systems child-friendly (International Juvenile Justice Observatory 2016) 36; Stephanie Rap, 'A Children's Rights Perspective on the Participation of Juvenile Defendants in the Youth Court' (2016) 24(1) The International Journal of Children's Rights 93 .

28 Grisso et al (n 3) 334; See also Dusky v. United States no 504 (United States Supreme Court, 8 April 196o) 402; Rap, 'The participation of juvenile defendants in the youth court' (n 27) 106 and 107 .

29 Defence for Children International Italy, 'TWELVE - Children's right to participation and the juvenile justice system (Defence for Children International Italy 2016); Rap, 'The participation of juvenile defendants in the youth court' (n 27) 107; UN Committee on the Rights of the Child (n 3), para 46.

30 Nicolson Siu, Heidi Lam, Jacqueline Le and Aneta Przepiorka, "Time perception and time perspective differences between adolescents and adults' (2014) 151 Acta Psychologica 222, 228 . 
delay, adolescents, including juveniles, have reduced capacity to 'anticipate the future and cope with delays' ${ }^{31}$

Because of their diminished capability to foresee and appreciate 'long-term consequences', juveniles tend to place their focus on immediate outcomes. ${ }^{32}$ Accordingly, juveniles may usually demonstrate a lack of patience and a desire to move rapidly through their court procedures, irrespective of the outcome. When court proceedings become extended, juvenile defendants may show reduced ability to contribute to their own defence towards securing an appropriate outcome for themselves. ${ }^{33}$ This can in turn hamper their 'competence to stand trial'.

Consequently, from a legal perspective, the 'passing of time' and delays may adversely affect the juvenile defendants' trial process. Within the setting of this situation, juveniles may end up in a disadvantaged and imbalanced position in comparison to the other parties in the proceedings in presenting their case, resulting in an unfair advantage for the prosecution. ${ }^{34}$ Accordingly, the 'equality of arms' principle may be harmed, hence contributing to ineffective and unfair justice.

Apart from a psychological perspective, it is also essential to reflect on the concept of 'reasonable time' from an educational (pedagogical) perspective. Within this context, the CRC Committee emphasises that the time between the commission of the offence and the conclusion of proceedings should be as short as possible. The longer this period, the more likely it is that the response loses its desired outcome' ${ }^{35}$ ('positive, pedagogical impact'). ${ }^{36}$

The CRC Committee further stresses that ' $\mathrm{t}]$ he passing of time is not perceived in the same way by children and adults. Delays in or prolonged decision-making have particularly adverse effects on children as they evolve., ${ }^{37}$ With particular reference to juveniles, the Beijing Rules underline that

31 Anne Mahoney, 'Time and Process in Juvenile Court' (1985) 10(1) The Justice System Journal 37, 39. See also Shepherd ( $\left.\mathrm{n}_{3}\right)$.

32 Lawrence Steinberg and Elizabeth Cauffman 'Maturity of judgment in adolescence: Psychosocial factors in adolescent decisionmaking' (1996) 2o Law and Human Behavior 249, 266; Grisso et al (n 3) 357; Butts, Cusick and Adams (n 3 ) 10.

33 Butts, Cusick and Adams (n 3) 10. See also Teeuwen (n 3).

34 Akther and Nordin (n 20).

35 UN Committee on the Rights of the Child (n 3), para 54.

36 UN Committee on the Rights of the Child, Children's rights in juvenile justice (2007). General Comment No 10, CRC/C/GC/10, para 51 (General Comment No 10, CRC/C/GC/10 has been replaced by General Comment No 24, CRC/C/GC/24).

37 UN Committee on the Rights of the Child, The Right of the Child to Have His or Her Best Interests Taken as a Primary Consideration (Art. 3, Para.1) (2013). General Comment No 14, CRC/C/CG/14, para 93 . 
The speedy conduct of formal procedures in juvenile cases is a paramount concern. Otherwise whatever good may be achieved by the procedure and the disposition is at risk. As time passes, the juvenile will find it increasingly difficult, if not impossible, to relate the procedure and disposition to the offence, both intellectually and psychologically. ${ }^{38}$

The Committee of Ministers of the Council of Europe specifically recommends 'ensuring that minors are treated more rapidly, avoiding undue delay, to ensure effective educational action' ${ }^{39}$

The view that lengthy delays reduce the educational effectiveness of punishment has been supported by research. If adjudication and disposition are delayed, the juvenile's perception of liability for their conduct is reduced and the ability to learn from their misstep will be impeded, which will consequently impact the effectiveness of the punishment. ${ }^{40}$ Relevantly, Jeffrey Butts and Joseph Sanborn argue that the impact of delayed procedures from the viewpoint of juveniles, specifically if exposed to prolonged delays between arrest and trial, can diminish the perceived consequences of their situation and subsequently negatively affect their future behaviours towards committing further offences, as the delays reduce any deterrence. ${ }^{41}$

Furthermore, as adolescence is often defined by phases of swift transformation, the reason for the offending behaviour, or the appropriateness of a selected punishment, may no longer be valid, considering the child's current and evolving developmental position. ${ }^{42}$

38 Beijing Rules, $\mathrm{r} 2 \mathrm{O}$.

39 Council of Europe Committee of Ministers, Recommendation No R (87) 20 of the Committee of Ministers to Member States on Social Reactions to Juvenile Delinquency (Committee of Ministers, 1987), para 4. See also Council of Europe, Guidelines of the Committee of Ministers of the Council of Europe on child-friendly justice (Council of Europe 2010), guideline 119 (Explanatory memorandum).

40 Jeffrey A Butts and Gregory J Halemba, Waiting for Justice: Moving Young Offenders Through the Juvenile Court Process (National Center for Juvenile Justice 1996) 4; Shepherd (n 3) 53; Katherine Federle, Children and the Law: An Interdisciplinary Approach with Cases, Materials and Comments (Oxford University Press 2013); Juvenile Justice Advocates International and the University of Minnesota Law School Human Rights Center (n 3$) 16$.

41 Jeffrey A. Butts and Joseph B. Sanborn (n 3) 18. See also Butts, Cusick and Adams (n 3) 8; Lubow (n 3$)$.

42 Mahoney (n 31) 39; Butts and Halemba (n 40) 4; Federle (n 40). 
This section will examine (1) the right to an effective remedy in case of a breach of a fundamental right, including the 'reasonable time' requirement, and (2) the right to legal representation. These two rights have been selected due to their potentially supporting nature, resulting in possible prevention of delay and compensation in the instance of a delay, as well as the importance of the role of the lawyer throughout the process in relation to the realisation of the defendants' remedial rights. Of these two rights, the right to an effective remedy has been examined to a greater extent, including case law analysis, due to its potentially high relevance in relation to supporting adherence to expeditious trials.

\subsection{Juveniles' Right to an Effective Remedy}

Research on the right to an effective remedy in case of a breach of an expeditious trial has been broadly conducted by several authors. ${ }^{43}$ Nevertheless, specific in-depth research in this area with a focus on juvenile defendants appears to be limited. Accordingly, the following section focuses on the right to an effective remedy, with an emphasis on juveniles.

Firstly, the significance and meaning of effective remedies will be explained. Secondly, it will be examined, to which extent the relevant human rights instruments and their governing bodies ${ }^{44}$ have addressed the right for juveniles to an effective remedy in case of a breach of a fundamental right, including the 'reasonable time' requirement, and whether the consequences, from a developmental, as well as psychological and educational perspectives, have been differentiated between adults and juveniles. Finally, this section will conclude with a description of the various forms of remedies generally applied by countries in case of delay and the extent to which these remedies can contribute to expeditious trial proceedings in juvenile cases.

\subsubsection{Significance of Remedies}

The human rights bodies provide some clarification on the relevance of effective remedies. The HRC underlines that 'in addition to effective protection' of

43 Brumar (n 5); Kamilovska ( n $_{5}$ ); Kuijer (n 5); Bleeker (n 5).

44 The objective of the analysis on the various human rights instruments and case law is to provide a more informed overview on the right to an effective remedy, as well as to initiate the foundation for further research on the Cambodian, Philippine and Vietnamese legislative frameworks. Consequently, the analysis solely focuses on the instruments relevant to the abovementioned three countries. 
the rights included in the International Covenant on Political and Civil Rights (ICCPR), 'States Parties must ensure that individuals also have accessible and effective remedies to vindicate those rights' ${ }^{45}$ Furthermore, the HRC adds: 'Cessation of an ongoing violation is an essential element of the right to an effective remedy'.6 The HRC also states that if there would be no requirement integral to article 2, to take measures (such as amendment of laws) to avoid a violation of the ICCPR from happening again, the ICCPR would have no purpose. ${ }^{47}$

The CRC Committee specifically highlights that '[f] or rights to have meaning, effective remedies must be available to redress violations'. The CRC Committee acknowledges that '[c]hildren's special and dependent status creates real difficulties for them in pursuing remedies for breaches of their rights. So States need to give particular attention to ensuring that there are effective, child-sensitive procedures available to children and their representatives' including 'access to independent complaints procedures and to the courts with necessary legal and other assistance'. The CRC Committee further sets forth that in case of a rights violation, applicable reparation should be available, including compensation, and if required 'measures to promote physical and psychological recovery, rehabilitation and reintegration' as set forth in article 39 of the Convention on the Rights of the Child (CRC). ${ }^{48}$

Moreover, 'the ability to obtain a just and timely remedy for violations of rights' as addressed by the national and international framework, including the CRC, has been referred to by the UN High Commissioner for Human Rights (High Commissioner) as 'access to justice', a concept which also covers 'all relevant judicial proceedings, affecting children without limitation', including children in conflict with the law. ${ }^{49}$ The High Commissioner explicitly states that children 'should be enabled to access relevant information and to effective remedies to claim their rights, including through legal and other services.'50

45 UN Human Rights Committee, The Nature of the General Legal Obligation Imposed on States Parties to the Covenant (2004). General Comment No 31 [80], CCPR/C/21/Rev.1/Add. 1326, para 15 .

46 ibid.

47 ibid para 17.

48 UN Committee on the Rights of the Child, General measures of implementation of the Convention on the Rights of the Child (arts. 4, 42 and 44, para. 6) (2003). General Comment No 5 , CRC/GC/2003/5, para 24 .

49 UN Human Rights Council, Access to justice for children (2013). A/HRC/25/35, para 4; Ton Liefaard, 'Access to Justice for Children Deprived of Their Liberty' in Center for Human Rights and Humanitarian Law, Anti-Torture Initiative (red), Protecting Children Against Torture in Detention: Global Solutions for a Global Problem (American University Washington College of Law 2017) 6o.

$5^{\circ}$ UN Human Rights Council (n 49), para 5. 
'Access to justice' is particularly significant for children deprived of their liberty, as it can 'safeguard equitable and child-rights treatment', 51 which fundamentally is the underlying aim of the CRC core principles concerning respecting the child's best interests and the rights to life, survival and development. ${ }^{52}$ The High Commissioner stresses that ' $[\mathrm{w}]$ ithout access to complaint mechanisms, these children face an increased risk of suffering abuse of authority, humiliation, ill-treatment and other unacceptable deprivation of rights.' ${ }^{53}$

\subsubsection{Meaning of Effective Remedies}

Effective remedies may be comprised of the most regular legal remedy, an appeal. More particular in the context of the 'reasonable time' requirement, specific preventive remedies exist to accelerate legal proceedings, including measures such as time-limits and priority lists, and compensatory remedies to compensate in case of delay, comprising of sentence reduction, case dismissal or financial compensation (see further section 3.1.5. below).

Although, the CRC Committee and the HRC do not provide an explicit definition of an 'effective remedy', both bodies do offer some guidance. The HRC notes that remedies must be properly adjusted to take the specific vulnerability of children into consideration. ${ }^{54}$ The CRC Committee highlights that it is of critical importance national legislative frameworks specify 'entitlements in sufficient detail to enable remedies for non-compliance to be effective.'55 In addition, States parties to the Optional Protocol to the Convention on the Rights of the Child on a Communications Procedure (CRC-OP3) should acknowledge that the best interests of the child should be a primary consideration to be respected in pursuing remedies for violations of the rights of the child, and that such remedies should take into account the need for childsensitive procedures at all levels. ${ }^{56}$

Moreover, although not specifically targeted towards children, the European Court of Human Rights (ECtHR) in its case law has identified a broad range of requirements necessary for a remedy to be 'effective', within the context of the meaning of article 13 of the European Convention on Human Rights (ECHR) (the right to an effective remedy). A remedy should be "effective" in practice,

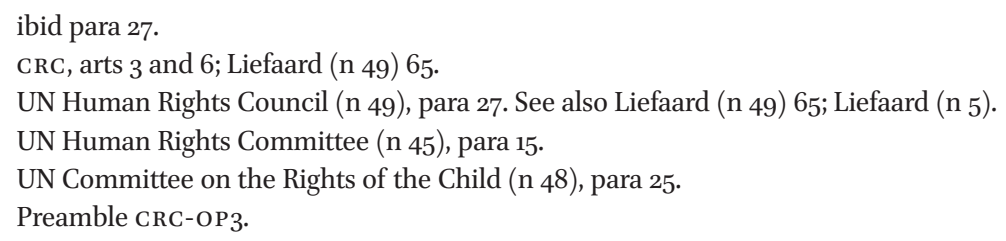


as well as in law', 57 give 'appropriate relief'58 and is 'available and sufficient'.59 Specifically in relation to lengthy proceedings, the ECtHR states that a remedy is 'effective' if it can be applied either to accelerate a decision, prevent the delay or to ensure 'adequate redress' is provided for delays that have already taken place. ${ }^{60}$

3.1.3 Juveniles' Right to an Effective Remedy: International Instruments As argued above in section 2 of this article, it is evident that a violation of the right to be tried within a reasonable time has a more substantial impact on juvenile defendants than on adults. Accordingly, it can be concluded that from a psychological, as well as an educational perspective, it would be imperative for the international instruments, human rights bodies, as well as the State parties, to ensure special or differentiated consequences and differing remedies be available between juvenile and adult cases in instances of a breach of the 'reasonable time' requirement. ${ }^{61}$ Such action will also create alignment with the international human rights instruments and their bodies entitling children to special protection taking into account their age. ${ }^{62}$

The Universal Declaration of Human Rights (UDHR) entitles 'everyone the right to an effective remedy by the competent national tribunals for acts violating the fundamental rights granted him by the constitution or by law' ${ }^{6}$ This specific right has been reinforced and expanded by the ICCPR in article 2 , including that 'any person whose rights or freedoms' as recognised in the ICCPR are violated is entitled to an effective remedy. ${ }^{64}$

More specifically, the HRC states that the right to an effective remedy set forth by the ICCPR must be considered whenever a right has been breached under article 14 of the ICCPR (fair trial rights). ${ }^{65}$ The explicit relationship

57 Kudta $v$ Poland App no 30210/96 (ECtHR, 26 October 200o), para 157; El-Masri $v$ the former Yugoslav Republic of Macedonia App no 3963o/o9 (ECtHR, 13 December 2012), para 255.

58 Aksoyv Turkey App no 21987/93 (ECtHR, 18 December 1996), para 95; Kudla v Poland (n 57), para 157 .

59 Riccardi Pizzati $v$ Italy App no 62361/oo (ECtHR, 29 March 2006), para 39; McFarlane v Ireland App no 31333/o6 (ECtHR, 10 September 2010), para 107.

6o Kudla v Poland (n 57), paras 158 and 159.

61 See also Bleeker ( $\mathrm{n}_{5}$ ).

62 ICCPR, art 14(4); CRC, art 4O(1); UN Human Rights Committee (n 45), para 15; UN Human Rights Committee (n 18), para 42; UN Committee on the Rights of the Child (n 3 ).

63 Universal Declaration of Human Rights (adopted 1o December 1948) UNGA Res 217 A (III) (UDHR), art 8.

64 ICCPR, art 2(3) (a).

65 UN Human Rights Committee (n 18), para 58. 
between the right to an effective remedy and the 'reasonable time' requirement has specifically been reflected in the HRC's case law. ${ }^{66}$

The correlation between remedies and lengthy pre-trial detention is also shown in the case law of the HRC. ${ }^{67}$ In the case Sahadeo v Guyana, ${ }^{68}$ the HRC found the applicant was entitled to an effective remedy, including compensation, as a result of the excessive pre-trial detention and the delay in the applicant's trial. ${ }^{69}$

The CRC Committee notes that, although the right to an effective remedy has not been explicitly set forth in the CRC, it is an implied obligation under the CrC. ${ }^{70}$ In addition, specifically with regard to juveniles, the United Nations Rules for the Protection of Juveniles Deprived of their Liberty (Havana Rules) stipulates: 'Where appropriate, States should incorporate the Rules into their legislation or amend it accordingly and provide effective remedies for their breach, including compensation when injuries are inflicted on juveniles. ${ }^{71}$

With respect to the relevant regional instruments, the ECHR entitles 'everyone' to an effective remedy before a national authority 'whose rights and freedoms' within the ECHR have been breached (Art. 13). 'Everyone' evidently covers children. ${ }^{72}$ The explicit relationship with article 13 ECHR and the 'reasonable time' requirement of article 6 ECHR was confirmed in Kudla v Poland, where the ECtHR considered 'that the correct interpretation of Article 13 is that that provision guarantees an effective remedy before a national authority for an alleged breach of the requirement under Article $6 \S 1$ to hear a case within a reasonable time. ${ }^{73}$

Furthermore, a relevant human rights instrument within the Asian region is the Asian Human Rights Declaration (AHRD) declaring that "[e]very person has the right to an effective and enforceable remedy, to be determined by a

66 See section 3.1.4 in this article on Case Law of HRC and ECtHR on Specific Remedies and the 'Reasonable Time' Requirement.

67 UN Human Rights Committee, Article 9: Liberty and Security of Person (2014). General Comment No 35, CCPR/C/GC/35, paras 49 and 51 .

68 Sahadeo v Guyana no 728/1996 (HRC, 1 November 2001), para 11.

69 Sahadeo v Guyana (n 68), paras 10 and 11; ICCPR, arts 2(3) (a), 9(3), 9(5) and 14(3) (c); UN Human Rights Committee (n 67), paras 49 and 51.

70 UN Committee on the Rights of the Child (n 48), para 24; UN Human Rights Council (n 49), para 11.

71 Havana Rules, $\mathrm{r} 7$.

72 Council of Europe (n 39), guideline 91 (Explanatory memorandum).

73 Kudla $v$ Poland (n 57), para 156. See also Council of Europe (n 12), paras 44 and 45; Kuijer (n 5) 785 . 
court or other competent authorities, for acts violating the rights granted to that person by the constitution or by law' (article 5 ). ${ }^{74}$

\section{1 .4}

Case Law of HRC and ECtHR on Specific Remedies and the 'Reasonable Time' Requirement

This section analyses the HRC and the ECtHR's decisions and judgments in relation to their approach to remedying cases in instances where State parties breach the 'reasonable time' requirement. Though the ECHR is not applicable to the Asian region, the ECtHR's case law provides some interesting perspectives and can serve as a comparative example with the HRC in relation to its remedies, which in the context of juveniles has had to date limited attention in academic research.

Individuals, including children, ${ }^{75}$ are entitled in case of a breach of the CRC, ICCPR or ECHR and after having exhausted remedies at a national level, to submit complaints directly to the CRC Committee, HRC and ECtHR, through the Optional Protocol to the Convention on the Rights of a Child on a Communications Procedure (article 5), the Optional Protocol to the International Covenant on Civil and Political Rights (article 2) and article 34 of the ECHR respectively.

In January 2018, the CRC Committee adopted its first view on the merits of a communication under the individual complaints mechanism in IAM (on behalf of KYM) $v$ Denmark. ${ }^{76}$ However, at the time of writing, the CRC Committee has not issued any case law concerning violations of the 'reasonable time' requirement in criminal cases and accordingly its case law has not been further analysed for the purpose of this article.

(a) HRC case law: The HRC is authorised to 'receive and consider communications from individuals subject to its jurisdiction who claim to be victims of a violation by that State Party of any of the rights set forth in the Covenant. ${ }^{77}$ In case the HRC determines a violation in a specific case, it demands that the State party provide a remedy following article 2(3) of the ICCPR, of which the HRC may provide recommendations on specific measures. ${ }^{78}$

74 At the time of writing, the ASEAN Human Rights Committee has not yet issued any case law.

75 On the condition that children are residing in the jurisdiction of countries which have committed to the treaty in question.

76 IAM (on behalf of KYM) $v$ Denmark no 3/2016 (CRC Committee, 25 January 2018).

77 Optional Protocol to the International Covenant on Civil and Political Rights (adopted 19 December 1966, entered into force 23 March 1976) 999 UNTS 171, art. 1.

78 UN Office of the High Commissioner for Human Rights (UNOHCHR), Fact Sheet No 15 (Rev.1), Civil and Political Rights: The Human Rights Committee (UNOHCHR 2005) 27. 
In case of a breach of the 'reasonable time' requirement of article 14(3)(c) of the ICCPR, the HRC provides recommendations to the State parties to be implemented, including individual measures, such as, 'taking steps to speed up the author's trial'79 or a 'prompt review of an appeal before the Court of Appeals and compensation for the undue delay' ${ }^{80}$

In Abdelhamid Taright et al. $v$ Algeria, the HRC required the State, as a result of the excessive pre-trial detention and delay in the applicant's trial, resulting in a breach of articles 9(1) and (3) and 14(3)(c) of the ICCPR, 'to provide the authors with appropriate reparation' ${ }^{81}$ In this case, and in the majority of similar cases, the HRC also requires the States to take general measures 'to prevent similar violations in the future'.

In the juvenile case Krasnova $v$ Kyrgyzstan (2010), the HRC decided that, amongst other violations, the 'reasonable time' requirement of article 14(3)(c) had been breached and consequently demanded the State party to provide an effective remedy to the victim, 'including a review of his conviction taking into account of the provisions of the Covenant, and appropriate compensation'82 and 'to prevent similar violations in the future'. ${ }^{83}$

In the juvenile case Vyacheslav Berezhnoy $v$ Russian Federation (2016), the HRC determined that 'article 9(3) and (4), article 10(2)(b), article 14(3)(b) and (c), and article 14(4), read in conjunction with article 24(1)' of the ICCPR had been violated. As a result, the State was obliged to provide an effective remedy and to 'inter alia, provide [the author] with adequate compensation, including reimbursement of court fines, legal costs and other related fees incurred'. The State party was further required 'to take all the steps necessary to prevent similar violations against juvenile offenders from occurring in the future.' 84

(b) ECtHR Case law: The ECtHR is authorised to 'afford just satisfaction' pursuant to article 41 of the ECHR: 'If the Court finds that there has been a violation of the Convention or the Protocols thereto, and if the internal law of the High Contracting Party concerned allows only partial reparation to be made, the Court shall, if necessary, afford just satisfaction to the injured party'.

In the majority of cases, the ECtHR, in case of a breach of the 'reasonable time' requirement, obliges the respondent State party to provide to the

79 Juan Peirano Basso v Uruguay no 1887/2009 (HRC, 29 October 2010), para 12.

$80 \quad$ Lumanog and Santos $v$ Philippines no 1466/2006 (HRC, 20 March 2008), para 10.

81 Abdelhamid Taright et al. v Algeria no 1085/2002 (HRC, 15 March 2006), paras 8.4, 8.5, 9 and 10 .

82 An example is monetary compensation, see UnонснR (n 78$) 27$.

83 Krasnova $v$ Kyrgyzstan no 1402/2005 (HRC, 29 March 2011), paras 9 and 10.

84 Vyacheslav Berezhnoy v Russian Federation no 2107/2011 (HRC, 5 December 2016), paras 10 and 11. 
'injured party' or 'victim' of excessively lengthy proceedings just satisfaction or payment of damages. ${ }^{85}$ Financial compensation in this regard may consist of pecuniary damage ('loss actually suffered...and loss, or diminished gain, to be expected in the future...'), non-pecuniary damage ('non-material harm', for example, mental anguish or physical distress), and costs and expenses. ${ }^{86}$

With regard to the correlation between delayed proceedings and damage, the ECtHR in its case law anticipates 'a strong but rebuttable presumption that excessively long proceedings will occasion non-pecuniary damage, ${ }^{87}$ including as a result of living in a state of uncertainty and anxiety about the outcome of the proceedings'. ${ }^{88}$ In Kudla $v$ Poland, the ECtHR acknowledged that the applicant had 'certainly suffered non-pecuniary damage - such as distress and frustration resulting from the protracted length of his detention and trial - which is not sufficiently compensated by the findings of violation of the Convention'. ${ }^{89}$

The ECtHR awarded the applicants in the juvenile criminal cases Assenov and Others $v$ Bulgaria, Koşti and Others $v$ Turkey and Nart $v$ Turkey, as a result of a breach of the 'reasonable time' requirement of article 5(3), a just satisfaction in respect of non-pecuniary damage. ${ }^{90}$ In the juvenile case Ferrantelli and Santangelo, the ECtHR decided that although the 'reasonable time' requirement of article 6(1) of the ECHR had been violated, the ECtHR did not require the State to provide a remedy, as the prescribed time period for claims submitted by the applicants for just satisfaction had expired. ${ }^{91}$

Besides just satisfaction in case of a breach of the ECHR, ECtHR judgments may, to support respondent States fulfilling their obligations pursuant to article 46 (implementation of judgments), provide directions on 'the general and/or, if appropriate, individual measures to be adopted in its domestic legal order' to prevent further violations in the future. ${ }^{92}$ Relevantly, the ECtHR stated in

85 The term 'financial compensation' or 'monetary award' is used to circumscribe and paraphrase the echr's term 'just satisfaction' (Council of Europe, Rules of Court (Council of Europe 2020)).

86 Council of Europe (n 85) 66 and 67.

87 Apicella v Italy App no 6489o/or (ECtHR, 29 March 2006), para 93.

88 Guillemin v France App no 19632/92 (ECtHR, 21 February 1997), para 63.

$89 \quad$ Kudlav Poland (n 57 ), para 165.

90 Assenov and Others v Bulgaria App no 9o/1997/874/1086 (ECtHR, 28 October 1998); Koşti and Others $v$ Turkey App no 74321/o1 (ECtHR, 3 May 2007); Nart v Turkey App no 20817/04 (ECtHR, 6 May 2008).

91 Ferrantelli and Santangelo $v$ Italy App no 19874/92 (ECtHR, 7 August 1996), para 65.

92 Vlad and Others $v$ Romania App nos 40756/o6, 41508/o7 and 50806/o7 (ECtHR, 26 February 2014), para 162. See also Suso Musa v. Malta App no 42337/12 (ECtHR, 9 December 2013), para 120; Aliyev v. Azerbaijan App nos 68762/14 and 71200/14 (ECtHR, 20 September 2018), para 222; Council of Europe, Guide on Article 46 of the European Convention on Human Rights (Council of Europe 2021). 
the operative part of the judgment in the criminal case Barta and Drajkó $v$ Hungary: 'To prevent future violations of the right to a trial within a reasonable time, the respondent State should take all appropriate steps, preferably by amending the existing range of legal remedies or creating new ones, to secure genuinely effective redress for violations similar to the present one. ${ }^{93}$

In the civil case Lukenda $v$ Slovenia (2005), ${ }^{94}$ the ECtHR held that besides monetary compensation for non-pecuniary damage and costs and expenses, the respondent State party was required through appropriate legal measures and administrative practices, [to] secure the right to a trial within a reasonable time'. The operative part of the judgment further specified: 'to prevent future violations of the right to a trial within a reasonable time, the Court encourages the respondent State to either amend the existing range of legal remedies or add new remedies so as to secure genuinely effective redress for violations of that right'. ${ }^{95}$

Following the adoption of the Lukenda judgment, Slovenia initiated several measures to eradicate 'court backlogs' through the development of the 'Lukenda project' (2005-2014). Additional resources were made available, such as clerks, as well as the development of an increased effective case management and monitoring system and informatisation process. ${ }^{96}$ Besides these measures, new legislation was introduced in 2006, consisting of the 'Act on the Protection of the Right to a Trial without Undue Delay'. This Act, covering civil and criminal cases, provides in an instance of delay for 'acceleratory remedies 97 'to expedite pending proceedings', comprising of 'a supervisory appeal

93 Barta and Drajkó v Hungary App no 35729/12 (ECtHR, 17 December 2013), para 49.

94 The pilot case Lukenda v Slovenia App no 23032/o2 (ECtHR, 6 October 2005) was intended to 'facilitate effective implementation by respondent States of individual and general measures necessary to comply with the Court's judgments', as well as to induce 'the respondent State to resolve large numbers of individual cases arising from the same structural problem at domestic level...' (Council of Europe, Press country Profile - Slovenia (Council of Europe 2019). See also Varga and Others v. Hungary App nos 14097/12, 45135/12, 73712/12, 34001/13, 44055/13 and 64586/13 (ECtHR, 10 June 2015), para 111; Rezmiveș and Others v. Romania App nos 61467/12, 39516/13, 48231/13 and 68191/13 (ECtHR, 25 July 2017), paras 106- 111.

Lukenda $v$ Slovenia (n 94), para 98. The author was unable to find juvenile cases, in which the ECtHR recommended general measures to secure the right to be tried within a reasonable time.

96 Tina Sever, Ana Đanić and Polonca Kovać, 'Effective Legal Protection against the Excessive Length of Administrative Decision-Making: The Cases of Slovenia and Croatia' (2016) 9(1) The NIsPacee Journal of Public Administration and Policy 135. See also Council of Europe (n 92).

97 Sever, Đanić and Kovać (n 96) 146. 
and a motion for a deadline to be set'. ${ }^{98}$ The Act in addition offers a compensatory remedy, including monetary compensation..$^{99}$

It can be concluded that the right of 'any person' or 'everyone' to an effective remedy in case of a breach of a fundamental right has been implicitly or explicitly incorporated in the relevant international and regional legislative framework, though without further specification. 'Any person' or 'everyone' includes juvenile defendants. More specifically however, whilst the right to an effective remedy in the case of a breach of the 'reasonable time' requirement is an implied right under the ICCPR and the ECHR, the correlation has been explicitly confirmed by the HRC and ECtHR's case law, in which decisions and judgments are required to be respected by State parties. ${ }^{100}$ Both the ICCPR and the ECHR do explicitly entitle victims to compensation in case of unlawful detention, of which the HRC's case law also cites in the instance when pre-trial detention is prolonged. ${ }^{101}$

Moreover, in relation to the analysis of the human rights bodies' case law, the HRC requires State parties, in the majority of its decisions concerning breaches of the 'reasonable time' requirement, in addition to individual actions, to take measures to prevent violations from happening in the future. However, it seems this guidance is absent from any specific direction on how best to achieve this outcome. This, in contrast to the ECtHR whose general recommendations of measures, such as the amendment of existing laws or development of new legislation, can be considered as positive examples for the HRC, providing some guidance for the State parties going forward on how to secure the right to a trial within a reasonable time. Consequently, these recommendations can have a positive impact encouraging State parties to initiate and implement measures for reform, as demonstrated in Slovenia, with a view to addressing the challenges surrounding delays in trial proceedings systematically.

Unfortunately, it appears that neither the instruments nor the HRC and ECtHR in their decisions and judgments have provided specific measures for the prevention of delay or the consequences for a breach of the 'reasonable time' requirement in juvenile cases. ${ }^{102}$

98 Šilih v Slovenia no 71463/o1 (ECtHR, 9 April 2009), para 102.

99 Sever, Đanić and Kovać (n 96) 146. See also Šilih v Slovenia (n 98), para 102.

$100 \mathrm{UNOHCHR}(\mathrm{n} 78)$; Council of Europe, The ECHR in 50 Questions (Council of Europe 2014).

101 ICCPR, art 9(3) and (5); ECHR art 5(3) and (5); Sahadeo v Guyana (n 68), paras 10 and 11.

102 See also Bleeker ( $\mathrm{n}_{5}$ ). 
Following the international and regional instruments and case law analysis, it is relevant to examine the various forms of available remedies. Firstly, the most regular legal remedy, an appeal, will be addressed, followed by specific kinds of remedies supporting expeditious trials.

(a) Appeal: A standard legal remedy is an appeal which aims 'to remedy court decisions brought by the court of first instance.'103 It is of great importance the 'basic procedural safeguards' are guaranteed throughout the appeal proceedings. ${ }^{104}$ The right to appeal is a fair trial right and has been recognised in the relevant international and regional human rights framework. ${ }^{105}$ The ICCPR entitles everyone convicted of a crime the opportunity of having the 'conviction and sentence being reviewed by a higher tribunal according to law'.106 The HRC further clarifies that this specific right requires State parties 'to review substantively, both on the basis of sufficiency of the evidence and of the law, the conviction and sentence, such that the procedure allows for due consideration of the nature of the case.'107 The HRC in addition stresses that this 'guarantee is not confined to the most serious offences,',108 which the CRC Committee reiterates in its General Comment No $24 .{ }^{109}$

Within the context of this article's topic, the right to an appeal is further intrinsically linked to the right to be tried within a reasonable time. The HRC notes in its case law that 'in order to enjoy the effective exercise of the right to have conviction and sentence reviewed by a higher tribunal according to law',110 'the convicted person is entitled to have, within a reasonable time, access to written judgments, duly reasoned, for all instances of appeal'.111 Article 14(3)(c) and (5) of the ICCPR 'are to be read together, so that the right

103 Vilard Bytyqi, 'The Right to Appeal as a Fundamental Right under International Acts and Jurisprudence, with Special Emphasis on Criminal Procedure' (2017) 13(1) Acta Universitatis Danubius. Juridica 13o. See also Peter D Marshall, 'A Comparative Analysis of the Right to Appeal' (2011) 22(1) Duke Journal of Comparative \& International Law 1.

104 Beijing Rules, $\mathrm{r}$ 7.1.

105 ICCPR, art 14(5); CRC, art 4O(2) (b)(v); Protocol no 7 to the ECHR, art 2; Beijing Rules, $\mathrm{r} 7(1)$; ACHR, art 8(2) (h); African Charter, art 7(1).

106 ICCPR, art 14(5).

107 UN Human Rights Committee (n 18), para 48.

108 ibid para 45 .

109 UN Committee on the Rights of the Child (n 3), para 62.

110 VFrancis $v$ Jamaica no 320/1988 (HRC, 24 March 1993), para 12.2.

111 Henryv.Jamaica no 23o/l987 (HRC, 1 November 1991), para 8.4. See also Baileyv Jamaica no 334/1988 (HRC, 31 March 1993), para 7.4; UN Human Rights Committee (n 18), para 49. 
to review of conviction and sentence must be made available without delay'.112 Furthermore, in order to ensure the effective compliance of the right to an appeal enshrined in article 14(5), the higher instance court's review must take place without delay, in compliance with article $14(3)(c) .{ }^{113}$

The CRC entitles every child in conflict with the law to the following: 'If considered to have infringed the penal law, to have this decision and any measures imposed in consequence thereof reviewed by a higher competent, independent and impartial authority or judicial body according to law'.114 The CRC Committee recommends State parties to 'consider introducing automatic measures of review, particularly in cases that result in criminal records or deprivation of liberty. Furthermore, access to justice requires a broader interpretation, allowing reviews or appeals on any procedural or substantive misdirection, and ensuring that effective remedies are available.'115

Regionally, the ECHR states that '[e]veryone convicted of a criminal offence by a tribunal shall have the right to have his conviction or sentence reviewed by a higher tribunal:'116 The right to an appeal is absent from the ASEAN Human Rights Declaration (AHRD).

(b) Remedies supporting expeditious trials: Within the context of specific remedies supporting expeditious trials, two main forms of domestic remedies available in countries will be addressed in the following section:(1) preventive/ acceleratory remedies, and (2) compensatory remedies.

Preventive/acceleratory remedies aim at speeding up or accelerating legal proceedings to 'prevent them from becoming excessively lengthy'.17 In this context, various countries 'provide for specific preventive remedies which aim at speeding up investigative or pre-trial proceedings by allowing for complaints or requests for acceleration to be lodged with the superior prosecuting or judicial authority'. Examples of means adopted by the relevant authorities in response may include, examining the drivers of the reported delays or a

112

\section{3}

V Francis $v$ Jamaica (n 110), para 12.2. See also Lumley $v$ Jamaica no 662/1995 (HRC, 31 March 1999), para 7.5.

Daleyv Jamaica no 750/1997 (HRC, 3 August 1998), para 7.4; Bennett v Jamaica no 59o/1994 (HRC, 10 May 1999), para 10.5; Brown and Parish v Jamaica no 665/1995 (HRC, 5 August 1999), para 9.5; Sextus $v$ Trinidad and Tobago no 818/1998 (HRC, 16 July 2001), para 7.3; Kennedy $v$ Trinidad and Tobago no 845/1998 (HRC, 26 March 2002), para 7.5; UN Human Rights Committee (n 18), para 49.

CRC, $\operatorname{art} 4 \mathrm{O}(2)(\mathrm{b})(\mathrm{v})$.

UN Committee on the Rights of the Child (n 3), para 62.

Protocol no 7 to the ECHR, art 2.

Council of Europe (n 12) 17. See also Brumar (n 5); Council of Europe, Guide to good practice in respect of domestic remedies (Council of Europe 2013) 25; European Union Agency for Fundamental Rights and the Council of Europe (n 12) 147 and 148. 
'request for follow-up reports' or setting 'time limits to conclude the investigative phase.'118 Other measures of preventive remedies are the provision of an 'immediate hearing date' as stated in the Handbook on European Law relating to Access to Justice ${ }^{119}$ or the assignment of cases on 'priority lists', as suggested by relevant literature. ${ }^{120} \mathrm{~A}$ drawback of a preventive remedy is that it can only be applied whilst the proceeding is still ongoing; after its completion, only a compensatory remedy can be requested. ${ }^{121}$

A compensatory remedy aims at compensating the person for whom the delay has already taken place. ${ }^{122}$ If an infringement of the 'reasonable time' requirement is determined to have transpired, the court may choose to provide redress. Means may include, a sentence reduction, ${ }^{123}$ an acquittal ${ }^{124}$ or a dismissal of the case. ${ }^{125}$ Particular compensatory remedies, may also function to some extent as a meaningful deterrent for the relevant judicial authorities to ensure they uphold rights, as they could be held accountable for the violation of rights (and consequences of their actions, or lack of), and as a result become more vigilant in its compliance. ${ }^{126}$

Both the HRC and the ECtHR prefer State parties to have preventive/ acceleratory remedies, rather than a compensatory one. The HRC specifically states that 'the mere possibilities of obtaining compensation after, and independently of, a trial that was unduly prolonged does not constitute an effective remedy' for the purpose of the ICCPR. ${ }^{127}$

The ECtHR emphasises in Scordino v Italy that 'the best solution in absolute terms is indisputably, as in many spheres, prevention':

Where the judicial system is deficient in this respect, a remedy designed to expedite the proceedings in order to prevent them from becoming

118 Council of Europe ( $\mathrm{n} 12$ ), paras 82 and 83 . See also the Act on the Protection of the Right to a Trial without Undue Delay of The Republic of Slovenia (2013), art 3.

119 European Union Agency for Fundamental Rights and the Council of Europe (n 12) 148.

120 Brumar ( $\left.\mathrm{n}_{5}\right) 829$.

121 ibid 827.

122 Council of Europe (n 12$) 17$.

123 For example, the Netherlands (ECLI:NL:HR:2000:AA7309: r.0. 3.5 and 3.6; ECLI:NL:HR: 2008:BD2578: r.o. 3.5.2).

124 For example, Estonia and Finland (Council of Europe (n 12 ) 21.

125 Sonja Starr, 'Sentence Reduction as a Remedy for Prosecutorial Misconduct' (2009) 97 The Georgetown Law Journal 1509 .

126 Sonja Starr, 'Rethinking "effective remedies": Remedial deterrence and international courts' (2008) 83 New York University Law Review 693; Starr (n 125).

127 Alfonso Ruiz Agudov Spain no 864/1999 (HRC, ${ }_{31}$ October 2002), para 9.1. See also Council of Europe (n 12) 31 . 
excessively lengthy is the most effective solution. Such a remedy offers an undeniable advantage over a remedy affording only compensation since it also prevents a finding of successive violations in respect of the same set of proceedings and does not merely repair the breach a posteriori... ${ }^{128}$

However, the ECtHR underlines that the best scenario for countries would be to have both types of remedies in place. ${ }^{129}$

In conclusion, a combination of preventive/acceleratory, as well as compensatory remedies would be an ideal model for countries to implement, in order to support expeditious trial proceedings for juveniles to the fullest extent. A mixture of both types of remedies will (1) ensure that the proceedings are expedited and therefore delays may be (to some extent) prevented, (2) provide compensation in the unfortunate situation that delays have already occurred, and (3) serve as a deterrent for the relevant judicial authorities to ensure the right to an expeditious trial is upheld.

\subsection{Juveniles' Right to Legal Representation}

Apart from the right to an effective remedy, the right of juveniles to legal representation is an additional procedural right, which when properly exercised can contribute to and support the fulfilment of expeditious trial proceedings. In this article 'the right to legal representation' refers to the right to legal and other appropriate assistance.

The right of juveniles to legal representation, including when deprived of their liberty, has explicitly or implicitly been incorporated in the relevant international and regional instruments. ${ }^{130}$ Pursuant to the ICCPR, everyone is entitled 'in the determination of any criminal charge against him'

[t]o defend himself in person or through legal assistance of his own choosing; to be informed, if he does not have legal assistance, of this right; and to have legal assistance assigned to him, in any case where the interests of justice so require, and without payment by him in any such case if he does not have sufficient means to pay for it. ${ }^{131}$

\footnotetext{
128 Scordino v Italy App no 36813/97 (ECtHR, 29 March 2006), para 183. See also Apicella v Italy (n 87), para 72; Cocchiarella v Italy App no 64886/o1 (ECtHR, 29 March 2006), para 74; Council of Europe (n 12) 31; Brumar (n 5 ).

129 Scordino $v$ Italy (n 128), para 186.

130 CRC, arts 37(d) and 4O(2) (b)(ii) and (iii); ICCPR, art 14(3)(d); ECHR, art 6(3) (c); Beijing Rules, r 15.1; Havana Rules, r 18(a); AHRD, art 2O(1).

131 ICCPR, $\operatorname{art} 14(3)(d)$.
} 
The HRC specifically highlights the relevance of this fundamental right for children and stresses that in criminal procedures juveniles should 'be provided with appropriate assistance in the preparation and presentation of their defence' and 'be tried as soon as possible in a fair hearing in the presence of legal counsel'.132

The CRC stipulates that a child is entitled to 'legal or other appropriate assistance' when progressing through the criminal justice process. ${ }^{133}$ However, in case children are deprived of their liberty, they 'have the right to prompt access to legal and other appropriate assistance. ${ }^{134}$ The CRC Committee, in its General Comment No 24, further clarifies 'other appropriate assistance':

If children are diverted to programmes or are in a system that does not result in convictions, criminal records or deprivation of liberty, "other appropriate assistance" by well-trained officers may be an acceptable form of assistance, although States that can provide legal representation for children during all processes should do so, in accordance with article 41. Where other appropriate assistance is permissible, the person providing the assistance is required to have sufficient knowledge of the legal aspects of the child justice process and receive appropriate training. ${ }^{135}$

The CRC Committee emphasises that the 'legal or other appropriate assistance' should be provided throughout all stages of the juvenile justice process and 'that effective legal representation' must be delivered 'free of charge'.136

The high relevance of access to (free) legal representation for children, including juveniles, is supported by literature. Children, by reason of their age, under-developed maturity, and emotional and cognitive capabilities, may encounter challenges to completely comprehend and exercise their rights and to take part in the criminal justice system effectively. ${ }^{137}$ Apart from their

132

133

134
UN Human Rights Committee (n 18), para 42.

CRC, art 4O(2) (b)(ii) and (iii).

(emphasis added) (Liefaard (n 5) 207 and 208); CRC, art 37(d).

UN Committee on the Rights of the Child (n 3 ), para $5^{2}$. 'Other appropriate assistance' can be provided by, for example, social workers (UN Committee on the Rights of the Child (n 36), para 49).

UN Committee on the Rights of the Child (n 3), paras 49 and 51 . See also Rap and Zlotnik (n 5); Liefaard ( $n_{5}$ ) 208; In the Handbook on European Law relating to access to justice, it is underlined that, "[t] he right to legal aid ensures effective access to justice for those who have insufficient financial resources to cover the costs of court cases, such as court fees or costs of legal representation' (European Union Agency for Fundamental Rights and the Council of Europe (n 12) 58. See also Liefaard (n 5 ) 208.

International Juvenile Justice Observatory (n 27) 33-37; Rap and Zlotnik (n 5) 119. 
developmental situation, children often lack the means to access advice and representation, being unfamiliar and inexperienced with legal procedures. ${ }^{138}$

The role of a lawyer is intended to protect children's rights and interests throughout the various stages of the criminal process, including undertaking legal actions to safeguard their rights and interests, ${ }^{139}$ which consequently will legally empower them. ${ }^{140}$ When juvenile defendants lack adequate legal representation, they may be incapable of navigating the 'complex' legal system effectively ${ }^{141}$ and accordingly encounter difficulties in comprehending and exercising their rights. ${ }^{142}$

Importantly, within the context of this article's topic, the guarantee of the right to legal representation is 'a foundation for the enjoyment of other procedural rights', including fair trial rights, ${ }^{143}$ such as the right to an expeditious trial. This correlation was confirmed by the HRC in the juvenile case Vyacheslav Berezhnoy $v$ Russian Federation (2016). In this case the HRC considered that, 'given the author's age at the time, which placed him in a vulnerable position, unimpeded access by his parent or legal guardian or legal representative ${ }^{144}$ could have played a crucial role in protecting his rights throughout the criminal proceedings'. Those rights included, amongst others 'the right to a speedy trial.'.145

In this regard, when juveniles exercise their right to legal representation, lawyers can assist them to obtain preventive/acceleratory remedies, through lodging complaints or requests to the relevant authorities ${ }^{146}$ on the expedition of proceedings. ${ }^{147}$ In addition, lawyers can, within the context of compensatory

$138 \quad$ UN Human Rights Council (n 49) para 40.

139 UN Human Rights Office of the High Commissioner, Basic Principles on the Role of Lawyers (UNO HCHR 1990), paras 13 and 14; UN Committee on the Rights of the Child (n 3) para 49; Rap en Zlotnik (n 5) 119 .

$140 \quad$ Liefaard (5) 207.

141 UN Human Rights Council (n 49), para 40.

142 International Juvenile Justice Observatory (n 27) 47-52; Rap and Zlotnik (n 5); Thi Thanh Nga Pham, 'Juvenile offenders in Vietnam and the right to defence' (2016) 16(1) Youth Justice 49,5 .

143 UN Office on Drugs and Crime, United Nations Principles and Guidelines on Access to Legal Aid in Criminal Justice Systems (United Nations 2013), paras 1 and 14. See also Pham (n 142) 50 .

144 (emphasis added).

145 Berezhnov $v$ Russian Federation (n 84) para 9.7.

146 Havana Rules, $\mathrm{r} 78$.

147 Council of Europe (n 12), para 82; See for example, legislation in the Netherlands (Dutch Code of Criminal Procedure, art 180), the Philippines (Revised Rules of Criminal Procedure of the Philippines, art 119, s 7) and Slovenia (Act on the Protection of the Right to a Trial without Undue Delay of the Republic of Slovenia, arts 3 and 5). 
remedies, also seek reparations on behalf of the juvenile, ${ }^{148}$ in case of a breach of the 'reasonable time' requirement. ${ }^{149}$ In the Netherlands, for example, lawyers can on behalf of their client request a sentence reduction. ${ }^{150}$

Cambodia, the Philippines and Vietnam have all ratified the CRC and ICCPR and adopted the AHRD; ${ }^{151}$ these instruments provide the foundation for the analysis below. At the time of writing, none of the abovementioned countries have signed or ratified the CRC-OP3. ${ }^{152}$ The legislative frameworks of Cambodia, the Philippines and Vietnam consist of their respective constitutions, domestic laws and secondary legislation. ${ }^{153}$ With regard to specific legislation covering children in conflict with the law, Cambodia adopted the Law on Juvenile Justice (JJ Law) in 2016, which came into effect in early 2017. The Philippines adopted the Juvenile Justice and Welfare Act of 2006 (No 9344), and Vietnam the Children Law (No 102/2016/QH13) in 2016.

148 UN Committee on the Rights of the Child (n 48), para 24.

149 See for example, Finland (Act on Compensation for the Excessive Length of Judicial Proceedings (2009), art 7).

15O ECLI:NL:HR: 2000:AA73O9: r.o. 3.5 and 3.6; ECLI:NL:HR: 2008:BD2578: r.o. 3.5.2.; R El Hessaini and YTaghi, 'Een onredelijke termijn en dan? Redelijke termijn in jeugdstrafzaken nader beschouwd' (2013) Tijdschrift voor Familie- en Jeugdrecht 298; Marije Jeltes, 'Rechterlijke ongehoorzaamheid met betrekking tot de overschrijding van de redelijke termijn in jeugdzaken: terecht?' (2015) 2 Tijdschrift Jeugdrecht in de Praktijk 25.

151 The CRC was ratified by Cambodia in 1992 and by both the Philippines and Vietnam in 1990. The ICC PR was ratified by Cambodia in 1992, the Philippines in 1986, and Vietnam in 1982. All three countries adopted the AHRD in 2012.

152 UN Human Rights Office of the High Commissioner, 'Status of Ratification Interactive Dashboard'(UN Human Rights Office of the High Commissioner 2021) <https://indicators. ohchrorg > accessed 27 January 2021.

153 Raoul Wallenberg Institute, A Measure of Last Resort? The Current Status of Juvenile Justice in ASEAN Member States (Raoul Wallenberg Institute 2015); with reference to their legal systems, Cambodia has a hybrid legal system composed of predominantly civil law elements combined with elements of common law and Cambodian customary law (Kong Phallack, Overview of the Cambodian legal and judicial system. In: Hor Peng, Kong Phallack and Jörg Menzel (eds), Introduction to Cambodian Law (Konrad-AdenauerStiftung 2012), 7-22). The Philippines has a mixed legal system of civil, common, Islamic and customary law, and Vietnam is based on the civil law system (Central Intelligence Agency (CIA), 'The world Facebook-Explore All Countries' < www.cia.gov/the-worldfactbook/countries/ > accessed 27 January 2021. 


\section{1}

\section{Juveniles' Right to an Effective Remedy}

\subsection{1}

Cambodia

Previous research and other relevant sources on Cambodia have indicated existing substantial challenges with regard to lengthy trial procedures for defendants, including juveniles. ${ }^{154}$ Encouragingly, the Royal Government of Cambodia has taken steps to address delays in trial procedures, highlighting that these delays have 'significantly increased the number of detainees, which affected the wellbeing of prisoners and hindered the provision of necessary services'. As a result, a working group was established in 2019 to 'streamline court procedures, with the aim of resolving prison overcrowding.' 155 In May 2020, a campaign was launched by the Ministry of Justice to systemically 'reduce prison overcrowding and increasing logjam of cases at Cambodia's courts by attempting to increase capacity at courts, accelerate trials and increase the use of bail and suspended sentences.' ${ }^{\prime 56}$

Regarding legislation, although specific duties for the Cambodian judiciary to secure the expeditiousness of proceedings and the 'prioritisation' of juvenile cases $^{157}$ have been addressed, the right to be tried within a reasonable time/

Aekje Teeuwen, Touch Chiva and Neth Tep, Securing Children's Rights in Cambodia: Pretrial detention and legal representation (Legal Aid of Cambodia 2006); Aekje Teeuwen, '2oth Anniversary of the UN Convention on the Rights of the Child' in Centre for Criminal Justice \& Human Rights Blog (Cork University 2009); Lo Leang, Report on the BaselineSurvey on the Situation of Children in Conflict with the Law in the Legal Process (Legal Aid of Cambodia 2011); UN Human Rights Council, Role and Achievements of the Office of the United Nations High Commissioner for Human Rights in Assisting the Government and People of Cambodia in the Promotion and Protection of Human Rights (2013). Report of the Secretary-General, A/HRc/24/32, para 38; LicAdho, Rights at a Price: Life inside Cambodia's Prisons (LICADHo 2015); UN Human Rights Council, Report of the Special Rapporteur on the Situation of Human Rights in Cambodia (2017). A/HRC/36/61, para 20; LICAdho, Time for Bail: Ending Needless Mass Detention (LICADHo 2018); Mech Dara, 'Slow process causes overcrowding' The Phnom Penh Post (Phnom Penh, 5 December 2018); UN Human Rights Council, Report of the Special Rapporteur on the Situation of Human Rights in Cambodia (2018). A/HRC/39/73, para 13(f); Mech Dara, 'Cases at court in push to tackle jail overcrowding' The Phnom Penh Post (Phnom Penh, 7 February 2019); Teeuwen $\left(\mathrm{n}_{3}\right)$.

155 Dara, 'Cases at court in push to tackle jail overcrowding' (n 154).

156 Hul Reaksmey, 'Justice Ministry: 'Reforms' Will Hasten Court Procedures to Reduce Prison Overcrowding' VOA Cambodia (Phnom Penh, 19 May 2020). See also Khuon Narim, 'New Justice Minister vows reforms and speedier trial procedures' Khmer Times (Phnom Penh, 2 April 2020); Khuon Narim, 'Clearing court backlogs' Khmer Times (Phnom Penh, 19 May 2020).

157 Criminal Procedure Code of the Kingdom of Cambodia 2007 (CPC), arts 304, 305 and 387; Law on Juvenile Justice (2016) (JJ Law), arts 34, 45 and 57. 
without (undue) delay, has not been explicitly incorporated as a constitutional or procedural right in the legislative framework, despite the ratification of the CRC and ICCPR which grant everyone this specific right. In addition, notwithstanding that pre-trial detention limits have been legislated, time limits between the various phases of the legal proceedings, including maximum adjudication time limits (for juveniles who are not in detention) appear to be absent from the law. ${ }^{158}$

Consequently, as the explicit right to be tried within a reasonable time is absent under Cambodian legislation, it is self-evident that Cambodia lacks the required legislation to remedy this right in case of an actual violation. Therefore, remedies have been examined across a broader spectrum.

Analysis has indicated that despite Cambodian legislation not explicitly covering the right to a remedy in case of a breach of a fair trial right, ${ }^{159}$ several provisions do implicitly refer to this specific right. For example, the Cambodian Constitution entitles Cambodian citizens 'to denounce, make complaints or file claims against any breach of the law by state and social organs or by members of such organs committed during the course of their duties. The settlement of complaints and claims shall be [within] the competence of the courts'.160 Nevertheless, domestic legislation appears to lack specific provisions on procedures and details related to complaint procedures and the form of available remedies to compensate for violations. ${ }^{161}$

Due to the absence of explicit legislation on remedies in relation to lengthy trials, including prolonged pre-trial detention, in the national legislative framework of Cambodia, it is interesting to refer to a case example from the Extraordinary Chambers in the Courts of Cambodia (ECCC). The ECCC, also known as the Khmer Rouge Tribunal, is a hybrid court ${ }^{162}$ established in

158 Teeuwen ( $\left.\mathrm{n}_{3}\right)$.

159 See also Extraordinary Chambers in the Courts of Cambodia (ECCC), no oo1/18-07-2007ECCC/sC (2012), para 391.

160 Constitution of the Kingdom of Cambodia (1993), art 39; Cambodian Civil Code (2011) in addition specifically states that individuals whose personal rights, such as 'the right to life, personal safety, health, freedom, dignity, and other personal benefits or interests', have been or may be violated, are entitled to have an injunction issued against the violator to stop the violation (art 11), 'demand elimination' of the continuing effect' of the violation, if any (art 12), and demand 'damages for any harm suffered' (art 13).

161 Although not classified as an effective remedy in case of a 'reasonable time' violation, the Criminal Code of the Kingdom of Cambodia (2009) does set forth that 'time spent in pretrial detention shall be wholly deducted from the term of imprisonment to be served' (art 51). See also CPC, art 503 .

162 A 'hybrid court' can be defined as: a 'mixed composition and jurisdiction, encompassing both national and international aspects...' (United Nations High Commissioner for 
2003 to prosecute the senior leaders of the Khmer Rouge, for alleged crimes, and ' $[t]$ hose believed to be most responsible for grave violations of national and international law', committed during the Cambodian genocide between $1975^{-1979.163}$

The most pertinent ECCC case is Case oo1, Kaing Guek Eav's (Duch), who was convicted in 2010 for 'crimes against humanity and grave breaches of the 1949 Geneva Conventions'.164 The Trial Chamber sentenced Duch to 35 years imprisonment; however, he received a five-year reduction as a remedy for his eight-year unlawful detention ${ }^{165}$ by the Cambodian military authorities, and in addition a sentence reduction for his time already spent in pre-trial detention. ${ }^{166}$

Although the ECCC's Supreme Court Chamber eventually overturned the verdict in 2012, repealed the five-year reduction remedy initially granted to Duch for his unlawful detention, and instead sentenced him to life imprisonment, ${ }^{167}$ the Trial Chamber judgment could serve as a good example for the Cambodian national judiciary, not only in relation to adults, but certainly also in juvenile cases. The ruling demonstrated (1) a way to remedy excessive pre-trial detention, and (2) that time should be taken into account for periods already spent in pre-trial detention. ${ }^{168}$ This specific trial illustrates that everyone has a right to a remedy in case of a breach of a fair trial right, regardless of his or her 'guilt or innocence.'169

Human Rights, Rule-of-Law Tools for Post-Conflict States: Maximizing the legacy of hybrid courts (United Nations 2008)) 1.

ECCC, 'Introduction to the ECCC' <www.eccc.gov.kh/en/introduction-eccc> accessed 27 January 2021.

164 ibid.

165 In the operative part of the decision on request of Duch's release in 2009, the Trial Chamber states that 'the accused's prior detention before the Military Court constitutes a violation of the Cambodian domestic law applicable at the time. It also contravenes his internationally-recognized right to a trial within a reasonable time and detention in accordance with the law' (ECCC, no oo1/18-07-2007/ECCC/TC (2009), para 21). ECCC, no 0o1/18-07-2007/ECCC/TC (2010), paras 679-681; ECCC (n 163). See also John Coughlan, Sana Ghouse and Richard Smith, 'The Legacy of the Khmer Rouge Tribunal: Maintaining the Status Quo of Cambodia's Legal and Judicial System' (2012) 4(2) Amsterdam Law Forum 16, 24.

167 ECCC, no oo1/18-o7-2007-ECCC/sc (2012), ch viII; ECCC (n 163).

168 Coughlan, Ghouse and Smith (n 166) 24.

169 ibid 25. 


\subsubsection{The Philippines ${ }^{170}$}

In contrast to Cambodia, the right to a speedy trial for accused persons has been explicitly included as a constitutional as well as a procedural right in the legislative framework of the Philippines. ${ }^{171}$ Albeit not directly stipulated in the Juvenile Justice and Welfare Act of 2006, the 2019 Supreme Court Revised Rules on Children in Conflict with the Law explicitly provides juveniles the right to a speedy trial. ${ }^{172}$ The Supreme Court has confirmed these Rules should be acknowledged and safeguarded by the court in all criminal proceedings. ${ }^{173}$

Specific time limits for trial proceedings in criminal cases have been specified by the Speedy Trial Act of 1998 and the Revised Rules of Criminal Procedure (2000). ${ }^{174}$ In case the accused is not brought to trial within the time limit provided under the law, both the Speedy Trial Act of 1998, ${ }^{175}$ as well as the Revised Rules of Criminal Procedure, ${ }^{176}$ provide for a remedy, specifying that 'the information may be dismissed on motion of the accused on the ground of denial of his right of speedy trial'. ${ }^{177}$

\subsubsection{Vietnam}

Pursuant to the Constitution of the Socialist Republic of Vietnam (2013) defendants 'must be tried timely... within the time provided by law'. ${ }^{178}$ The Criminal Procedure Code (2015) (CPC) in addition has included several provisions requiring 'timely' proceedings, ${ }^{179}$ including time limits at the investigation, prosecution, and trial stages, including appeal. The duration depends on the seriousness of the alleged crime, irrespective of the age of the defendants. 180

170 The author intends to conduct a more comprehensive comparative research on Cambodia, the Philippines and the Netherlands on 'reasonable time' and 'remedies' which will be published in a future article.

Constitution of the Republic of the Philippines (1987), art III, ss 14(2) and 16; Revised Rules of Criminal Procedure (As amended, December 1, 2000), r 115, s 1(h). 2019 Supreme Court Revised Rule on Children in Conflict with the Law, s 37(k).

173 Raoul Wallenberg Institute (n 153) 117.

174 Speedy Trial Act of 1998, ss 6-9; Revised Rules of Criminal Procedure (200o), r 119, ss 1 and 2.

$175 \mathrm{~s} 13$.

176 s 9.

177 Revised Rules of Criminal Procedure, s 9. See also the Guidelines for Decongesting Holding Jails by Enforcing the Rights of Accused Persons to Bail and to Speedy Trial, s 9. It is assumed that 'the information may be dismissed' implies that 'the case may be dismissed' as set forth in the Guidelines, ibid.

178 Constitution of the Socialist Republic of Vietnam (2013), art 31(2).

179 Criminal Procedure Code (no 101/2015/QH13) (2015) (CPC), arts 2 and 25.

180 CPC, arts 172, 240, 277 and 346. 
The CPC specifically requires that cases involving juveniles 'must be settled in swift and timely manners'. 181 The Children Law $(2016)^{182}$ requires that 'cases relating to children['s] affairs shall be promptly handled for minimizing mental and physical harm to children.' 183

It appears the Vietnamese legislative framework does not explicitly provide for the right to a remedy in case of a violation to 'be tried timely'. Nevertheless, this right has been implicitly specified in the Constitution providing that '[a] ny person who has been arrested, held in custody, prosecuted, investigated, charged or brought to trial in violation of the law shall be entitled to compensation for material and psychological damages and restoration of honour.'184

In conclusion, contrary to Cambodia, both the Philippines and Vietnam do explicitly entitle all defendants, including juveniles, to a speedy (the Philippines) and timely (Vietnam) trial, and provide for (adjudication) time limits in their legislative frameworks. In comparison, the Philippines appears to have the strongest legislation on compensatory remedies in relation to a denial of an expeditious trial, providing for a potential dismissal of the case. Vietnam's legislation is broader entitling compensation for people 'brought to trial in violation of the law' which can include the violation of the right to be tried timely. Regrettably, none of the three countries have incorporated into their legislative frameworks either preventive or compensatory remedies specifically for juveniles.

\subsection{Juveniles' Right to Legal Representation \\ 4.2.1 Cambodia}

The right to legal representation has been broadly incorporated within the Cambodian legislative framework, as a constitutional, as well as a procedural right. ${ }^{185}$ Regrettably, pursuant to the CPC, detainees in police custody are not entitled to access legal representation during the first 24 hours of their arrest. ${ }^{186}$ Consequently, this specific provision may create a risk for defendants of being vulnerable to forms of abuse during those initial 24 hours. ${ }^{187}$

\footnotetext{
181 ibid art 414(7).

182 In the Children Law (no 102/2016/Q H13) (2016), 'a child' is defined as 'a human being below the age of 16', which is not in compliance with the definition of the CRC, specifying 'a child' as a person below 18 years of age.

183 Children Law, art 70(2).

184 Constitution of the Socialist Republic of Vietnam, art 31(5). See also CPC, art 31.

185 Constitution of the Kingdom of Cambodia, art 38; CPC, arts 100, 143 and 301.

186 CPC, art 98. See also Niem Chheng, 'Lawyers seek right to meet arrested clients within 24 hours' The Phnom Penh Post (Phnom Penh, 13 October 2020).

187 UN Human Rights Committee, Concluding observations on the second periodic report of Cambodia (2015). CCPR/C/KHM/CO/2, para 17; Chheng (n 186).
} 
In relation to juveniles, the CPC specifically guarantees a child's right to legal representation during the trial stage, requiring that a child must have the assistance of a lawyer and, if there is no one available, one shall be appointed. ${ }^{188}$ The JJ Law entitles juveniles to legal representation throughout all the stages of the criminal process ${ }^{189}$ and 'from the earliest possible time of procedure,'190 which inherently implies including the first 24 hours of their arrest. More specifically, Cambodian legislation lacks specific provisions addressing duties for lawyers to request for the acceleration of cases. ${ }^{191}$

Although the Cambodian legislation clearly entitles defendants, including juveniles, to legal representation, the implementation of this specific right remains a challenge, as addressed in various concluding observations by human rights bodies directed at Cambodia and other relevant sources. Concerns are generally linked to the shortage of (pro bono) lawyers in Cambodia, which consequently leads to inadequate access to legal representation for defendants, including children, in the various stages of the proceedings. Accordingly, the HRC, CRC Committee and Committee Against Torture (CAT) are urging Cambodia to ensure legal representation is provided throughout all the phases of the criminal process. ${ }^{192}$

\subsubsection{The Philippines}

In the Philippines, the right to legal representation has been enshrined as a constitutional as well as a procedural right. ${ }^{193}$ The right to have legal and other appropriate assistance for children in conflict with the law has been reinforced in section $5(\mathrm{e})$ of the Juvenile Justice and Welfare Act and section 37 (d) of the 2019 Supreme Court Revised Rule on Children in Conflict with the Law.

\footnotetext{
188 CPC, art 301.

189 JJ Law, arts 6, 18, 21, 22, 26, 35 and 5o.

190 ibid art 6.

191 Notwithstanding this absence, some Cambodian juvenile lawyers do petition the relevant authorities to expedite proceedings on the basis of CPC, art 249 .

UN Committee on the Rights of the Child, Concluding Observations: Cambodia (2011). CRC/C/KHM/CO/2, paras 76(b) and 77(c); UN Committee against Torture, Concluding Observations: Cambodia (2011). CAT/C/K HM/CO/2, para 14; UN Human Rights Committee, Concluding observations on the second periodic report of Cambodia (2015). ССР /C/К HM/ co/2, para 17. See also Glenn Dawes, 'Young Cambodians as Victims of Institutional Violence in the Criminal Justice System' (2016) 11(1) Asian Journal of Criminology 33; Erin Handley, 'New law 'urgent,' but imperfect' The Phnom Penh Post (Phnom Penh, 29 December 2016); Voun Dara 'Legal aid for Kingdom's vulnerable' The Phnom Penh Post (Phnom Penh, 10 December 2018).

Constitution of the Republic of the Philippines, art III, s 11; Revised Rules of Criminal Procedure, r 115 (c).
} 
Interestingly, specific duties have been incorporated in the Revised Rules of Criminal Procedure for public attorneys when an accused is detained, requiring them to inform the defendant about his/her right to demand a trial and accordingly bring this into action if the defendant wishes to execute this specific right. ${ }^{194}$

\subsubsection{Vietnam}

In Vietnam, the right to a defence is clearly recognised in the law as a constitutional, as well as a procedural right. ${ }^{195}$ The CPC specifies that juveniles have the right 'to defend themselves and be defended.' ${ }^{196}$ Unusually, the CPC further states that representatives of juvenile offenders are 'entitled to select a defence counsel' or may choose to themselves defend the juvenile. ${ }^{197}$ It appears from these provisions that it allows the representatives of juvenile offenders 'to play the role of counsel', even though he/she would lack the professional background and requirements necessary for this position, ${ }^{198}$ as required by the CRC Committee. This could result in a scenario where the professional experience and trained skills required to assist juvenile defendants in preparing for and presenting their defence throughout the criminal process could not be safeguarded. 199 This could potentially also negatively impact the support to the juveniles' right to an expeditious trial, as the representative may be unaware how and which proceedings can contribute to realising this specific right. ${ }^{200}$ The Children Law has included further provisions entitling children to a defence and legal assistance. ${ }^{201}$ Under the CPC, defence counsel is entitled to 'petition for legal proceedings according to this Law' and to 'file complaints about competent procedural authorities and persons' decisions and legal proceedings.'202

In conclusion, all three countries have incorporated the right of juveniles to legal representation into their national legislative frameworks. However, it appears Vietnam does not fully adhere to the international standards in relation to juveniles' representatives being allowed to act as counsel; consequently

194

195

196

197

198

Revised Rules of Criminal Procedure, art 119, s 7. Constitution of the Socialist Republic of Vietnam, art 31(4); CPC, art 16. CPC, art 422(1). ibid art 422(2). Pham (n 142) 55 . ibid. See also Council of Europe (n 39), guideline 39; UN Office on Drugs and Crime (n 143); International Juvenile Justice Observatory (n 27) 51 and 52.

CPC, art 422(2) may also create a possible conflict of interest between children and their parents (Council of Europe (n 39), guidelines 37 and 42; UN Committee on the Rights of the Child (n 3), para 56).

Children Law, arts 30 and $70(5)$.

$\mathrm{CPC}$, art $73(\mathrm{~g})$ and $(\mathrm{n})$. 
this may not fully contribute to an expeditious trial for juveniles. Furthermore, it appears the Philippines has the strongest legislation in relation to preventive/ acceleratory remedies, explicitly providing duties for public attorneys to assist detained defendants in their right to demand a trial.

The 'reasonable time' approach and its linkage to 'juvenile defendants' has been further conceptualised in this article. It demonstrates the potential negative impacts of delay in criminal trial proceedings from a psychological and educational perspective, as well as the positive effects supporting rights may have on the reasonable time requirement. This had not been addressed to the same extent in previous literature.

The analysis in this article demonstrates that in exercising the right to an effective remedy, as well as the right to legal representation, juveniles have an increased likelihood that their right to an expeditious trial will be realised. Both these supporting rights have been explicitly and implicitly incorporated into the relevant international human rights standards and case law. Effective remedies may, in addition to speeding up proceedings and providing compensation in case of a breach of the 'reasonable time' requirement, also function as a meaningful deterrent for the relevant judicial authorities to avoid delay. The role of the lawyer is fundamental throughout the process to assist juveniles in the fulfilment of their remedial rights.

In the context of juvenile defendants, lengthy trial proceedings and delays have a greater negative impact on them compared to adults as there is more at stake as a result of their level of development and more vulnerable status. Consequently, in relation to remedies, it can be argued that from a psychological (competency to stand trial), as well as an educational perspective, preventive measures to avoid delays, as well as the consequences in case of a breach of the 'reasonable time' requirement, should be differentiated between adult and juvenile defendants. These measures/consequences should be made more stringent in cases involving juveniles, commensurate with the increased impact on them. However, following this article's analysis, it appears neither the international human rights instruments nor the HRC and ECtHR have differentiated between the two.

It is proposed to the CRC Committee and the HRC to jointly develop a general comment addressing fair trial rights in juvenile justice, with a focus on remedial options related to the 'reasonable time' requirement, and to distinguish its application between adults and juveniles. Furthermore, the HRC should in its decisions regarding 'reasonable time' violations, similarly to the practices of 
the ECtHR, provide State parties with further guidance on general measures to be taken to prevent, as well as compensate for, lengthy proceedings.

In addition, State parties, including Cambodia, are recommended to explicitly entitle by law juvenile defendants to appropriate and just remedies in relation to the right to an expeditious trial. In this context, remedies should preferably be a combination of both preventive/acceleratory as well as compensatory measures and differentiate between adult and juvenile cases.

More specifically, as for preventive/acceleratory remedies, countries should incorporate stricter (adjudication) time limits for juveniles compared to adult defendants and set clear procedures on the placement of juvenile cases on priority lists into their legislative frameworks. As for a compensatory remedy, dependent upon the circumstances, a potential sentence reduction or dismissal of the case could be considered, which could be applied with enhanced leniency in a situation where a juvenile is involved. The implementation of one of these measures could be considered just, as the majority of juvenile cases involve misdemeanor offences; as such, extended proceedings, specifically whilst in pre-trial detention, are disproportionate to the gravity of the offence. However, it should be recognised that in case of serious offences in which a victim is involved, compensatory remedies proportionate to the circumstances of the juvenile offender and to the severity of the offence may be contemplated, including consideration of the victim's situation, as well as the need for public safety.

Finally, in order to ensure the fulfillment of these remedial rights to the maximum extent, the lawyer's duties and responsibilities to demand a trial, as well as for compensation should be clearly legislated. In addition, the provision of training and awareness raising for legal professionals on juvenile justice and the role of the lawyer to ensure its compliance effectively should be considered.

As to the comparative analysis between Cambodia, the Philippines and Vietnam on the incorporation of the two supporting rights, it appears that theoretically the Philippines sets forth the strongest legislation on remedies and legal representation, which accordingly provides the most solid support for the fulfilment of the right to an expeditious trial for juveniles and could serve as a positive example for Cambodia. However, further research in relation to the Philippines is required to assess its actual efficacy and implementation in practice. 